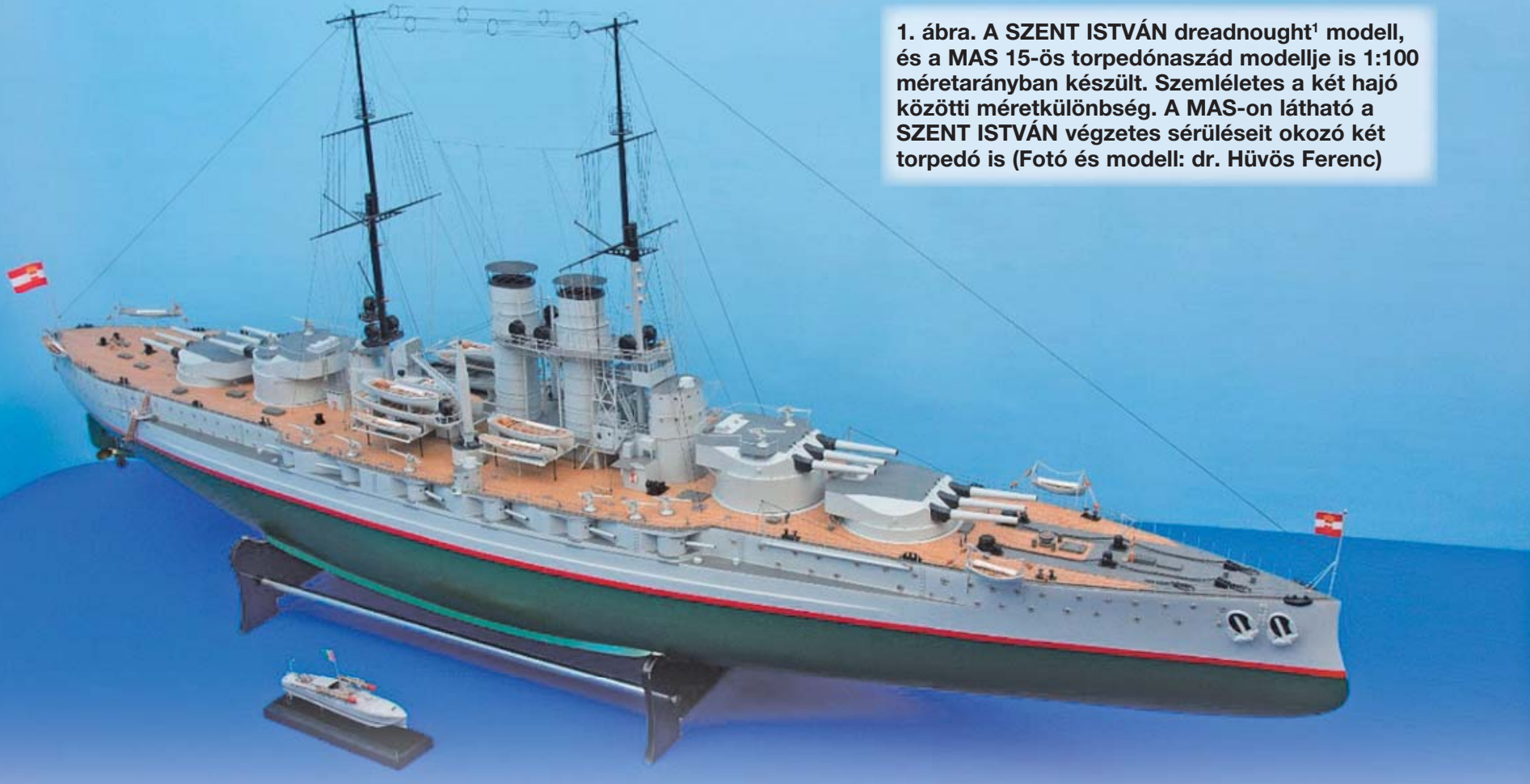

Sárhidai Gyula* - Demeterné Szivák Petra**

\title{
A SZENT ISTVÁN dreadnought pályafutása
} 1912-1918

A K.u.K. hadiflotta fejlesztését az határozta meg, hogy az Olasz Királyság 1882-1915 között a Központi Hatalmak (Hármas Szövetség: Németország, Ausztria-Magyarország és Olaszország) tagja volt. Ekkor nem volt ellenség, háború esetén az olasz-osztrák-magyar erők a Földközi-tengeren harcoltak volna. 1914 nyarán Olaszország (az antant hatalmak ígéreteinek hatására) nem hadviselő félnek nyilvánította magát, ezzel a szövetség kezdett felbomlani. 1915 májusában beállt a hadiállapot Olaszországgal, és az erőviszonyok kedvezőtlenné váltak az olasz-francia-angol erőkkel szemben. Ezért a K.u.K. nagy hajóegységei tétlenségre kényszerültek.

Az 1905-ben, Fiumében létesült Danubius Hajógyár rövid idő alatt nagy fejlődésnek indult. 1906-tól kezdődően a Fiume egyik külvárosában lévő hajóépítő műhelyt - az Angol-Osztrák Bankon keresztül lebonyolított brit pénzügyi segítséggel - fontos hajóépítő műhellyé bővítették. A magyar hadihajógyártás ennek következtében növekedő részaránya az 1. táblázat adatai alapján követhető nyomon.

ÖSSZEFOGLALÁS: 2018. június 10-én lesz 100 éve, hogy Ausztria-Magyarország flottájának SZENT ISTVÁN dreadnoughtja hullámsírba került. Ez volt az egyetlen, a Magyar Királyság területén, magyar gyárban épült dreadnought.

KULCSSZAVAK: K.u.K. haditengerészet, dreadnought, SZENT ISTVÁN, magyar hadiipar
1. táblázat. A magyar hajógyártás részaránya (1900-1915)²

\begin{tabular}{|l|c|c|}
\hline \multicolumn{1}{|c|}{$\begin{array}{c}\text { Hadihajó } \\
\text { kategória }\end{array}$} & $\begin{array}{c}\text { Névleges } \\
\text { vízkiszorítás }\end{array}$ & $\begin{array}{c}\text { Építési darabszám } \\
\text { osztrák/magyar }\end{array}$ \\
\hline $\begin{array}{l}\text { Dreadnought, } \\
\text { páncélos hajó }\end{array}$ & $10600-20000 \mathrm{t}$ & $9 / \mathbf{1}$ \\
\hline $\begin{array}{l}\text { Páncélos- és } \\
\text { gyorscirkáló }\end{array}$ & $3500-4300 \mathrm{t}$ & $3 / 2$ \\
\hline Torpedóromboló & $380-400 \mathrm{t}$ & $2 / 17$ \\
\hline Torpedónaszád & $200-250 \mathrm{t}$ & $4 / 2$ \\
\hline Tengeralattjáró & $230 \mathrm{t}$ & $5 / 2$ \\
\hline Monitor & $520 \mathrm{t}$ & $1 / 3$ \\
\hline
\end{tabular}

A 4 hajóból álló dreadnought osztály tervezése 1908 februárjában a kvótabizottság döntése nyomán kezdődött. A költségvetési bizottság hosszas huzavona után csak a

ABSTRACT: On 10 June 2018, 100 years will have passed since the dreadnought of the fleet of Austro-Hungary sank into watery grave. It was the only dreadnought built in a Hungarian factory in the territory of the Kingdom of Hungary.

KEY WORDS: Imperial and Royal Navy, dreadnought, SZENT ISTVÁN (King Saint Stephen), Hungarian defence industry

\footnotetext{
* Mérnök, Haditechnikai Intézet volt főelőadó, Haditechnika folyóirat korábbi szerkesztő, ORCID 0000-0002-2008-7997

** MH Logisztikai Központ, Technológiai Igazgatóság, Kutatás-fejlesztési, Tudományos és Szabványosítási Osztály, Haditechnika szerkesztő asszisztens, DOI adminisztrátor. ORCID: 0000-0002-5040-8739
} 


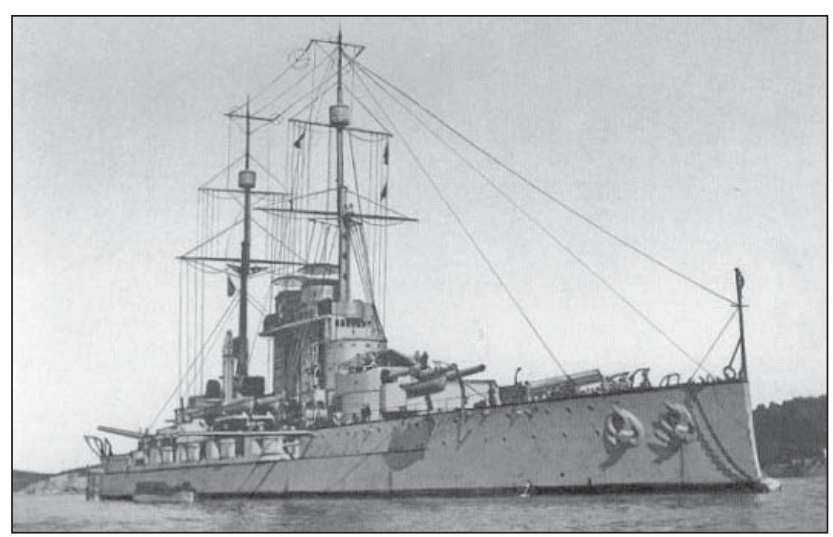

2. ábra. A hajó - már az 1917-es átépítés utáni állapotban - a pólai hadikikötőben horgonyoz

pénz egy részét szavazta meg. Ekkor a magyar királyi kormány beavatkozott és kipótolta a hiányzó részt, de cserében azt követelte, hogy a kvóta arányában a flotta megrendeléseinek 25\%-át magyar üzemek kapják. Tette ezt úgy, hogy a magyar hadiipar, főleg a gépipar színvonala, kapacitása, gyártástechnológiája messze elmaradt a szükségestől. Kifejezetten a dreadnought szerződés kedvéért, a magyar kormány 1910-ben lépéseket tett annak érdekében, hogy a hajógyárat ennek a feladatnak megfelelően modernizálja. A gyártó cég a Fiumei Danubius Hajó és Gépgyár Rt. volt. A modernizálás, illetve cégfejlesztés magába foglalta a Ganz Gépgyár és Kohóművek egyesítését a Danubius hajógyárral. 1911-től, az egyesülés után, az üzem neve Ganz és Társa Danubius Gép, Waggon és Hajógyár Rt. (Ganz és Tsa. Rt.) Budapest-Fiume lett. Az egyesülés a magyar kormány határozott kívánságára történt.

A SZENT ISTVÁN dreadnought-ot a hazai tulajdonban lévő Ganz és Tsa. Rt. hajógyár magyar költségvetési öszszegből gyártotta Fiumében, építésébe számos magyar cég szállított be részegységeket (Ganz: villamos berendezések, Weiss Manfréd: tüzérségi lőszerek, különféle budapesti gyárak - pl. Schoeller - és Diósgyőr: kovácsolt fémáruk, lemezek és öntvények.) A Ganz-Danubius mérnökei önálló kutatás-fejlesztés keretében hozták létre a SZENT ISTVÁN gőzturbinájának „zárt rendszerű, pumpából, tartályból és vízhűtő rendszerből álló kenőolajozó rendszerét, amelynek a tengerészeti műszaki bizottság előírta utólagos beépítését a még épülő TEGETTHOFF és PRINZ EUGEN dreadnoughtokba is. Az újításért (szabadalomért) a haditengerészet külön fizetett a Danubiusnak."3 A SZENT ISTVÁN 60 millió koronás költségvetéséből a magyar vállalkozások összességében 32,34 milliós részegység-beszállítói részaránnyal rendelkeztek, 14 milliós értékben beszállítva a hajótest építésébe, illetve 7 milliós értékben a gépészetei rendszerekbe. ${ }^{4}$

Annak ellenére, hogy a SZENT ISTVÁN dreadnoughtot hazai tulajdonban lévő hajógyár, magyar költségvetési öszszegből gyártotta, a hajó néhány részegysége nem hazai üzemben készült. Számos nehézfegyvert nem is lehetett Magyarországon legyártani, így a SZENT ISTVÁN jelentős részeit külföldi gyárak szállították le. A teljes tüzérséget a csehországi Škoda ágyúgyár, az acélanyagát a Witkovitzi Vasművek, a 12 db kazánját a Babcock-Wilcox típusból részben Svájcból, a 2 db AEG (Allgemeine Elektrizitäts Gesellschaft) - Curtiss gőzturbináját német üzemből hozták be. A nagy távmérők Barr \& Stround darabokból álltak, osztrák üzem rakta össze, a rádiók nagy része Telefunken alkatrészekből állt. Ugyanakkor Erwin F. Sieche hajózási szakíró szerint „a SZENT ISTVÁN esetében hangsúlyozni

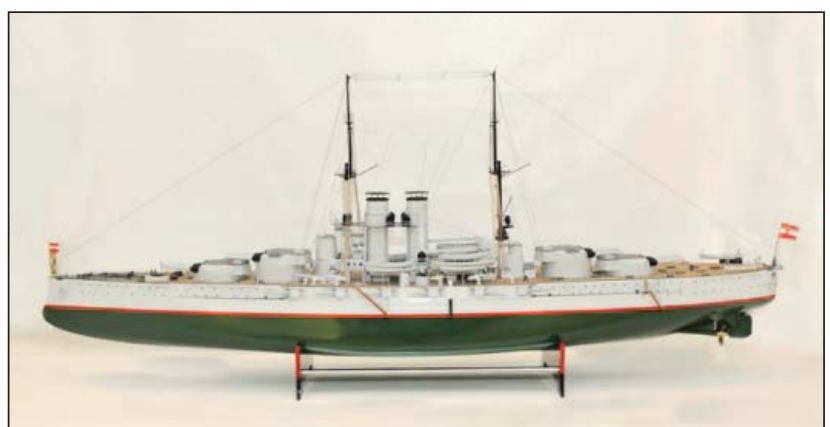

3. ábra. A SZENT ISTVÁN dreadnought napjainkban készített modellje, amely az 1917 utáni állapotot mutatja

kell a hajó magyar nemzetiségét... Magyarország nem akart csupán a haditengerészet szén- és élelmiszerszállítója lenni. Röviden, Magyarország csak akkor egyezik bele a teljes dreadnought alakulat megépítéséhez szükséges külön-alapok megszavazásába, ha megépítheti saját dreadnoughtját... A Fiume környéki tengerpart Magyarországhoz tartozott, és Magyarország mindent megtett, hogy kikötője Trieszt vetélytársává váljék a kereskedelemben és a hajóépítésben." 5

A kétturbinás megoldás miatt át kellett tervezni a hajó gépházát és a farát, mert 4 hajócsavar helyett csak $2 \mathrm{db}$ 4 méter átmérőjű példány volt. A hajó áttervezését magyar mérnökök végezték (Kaplanek József főkonstroktőr, Zimlitz József főmérnök, Mazurka, Ferdinánd és Hegedűs mérnökök). ${ }^{6}$ A két hajócsavaros megoldás (a négy helyett) a sebességnek nem használt, a hajó tartós maximális sebessége alig érte el a 20 csomót. A hajótest alakja kedvezőtlen volt, mert az alaptípust a Stabilimento Tecniko Triestino gyárhoz tervezték, ezért lett a hossza 152 méter, amely a 28 méteres szélességhez kevés. A trieszti gyárban a sólya mérete nem engedett többet. Fiumében még ennyi hely sem volt, a domboldalból lerobbantottak 40 métert, hogy a sólyát meghosszabbítsák, így éppen hogy elfért.

A SZENT ISTVÁN dreadnoughton 19 rekeszfal a hajótestet 20 vízhatlan kamrára osztotta fel, növelve a harci túlélőképességet. A hajó páncélvédelme $(280 \mathrm{~mm})$, méretéhez képest erősnek volt mondható, különösen az olasz csatahajók 250 mm-es páncélzatához képest. A vízvonalon az övpáncél 280 mm-es volt, a lövegtornyokat, azok barbettáit és a parancsnoki tornyot is ilyen vastagságú páncél védte. Az öv felső része, illetve a $15 \mathrm{~cm}$-es lövegek kazamatáinak páncélzata $180 \mathrm{~mm}$ vastag volt. A páncélfedélzet középen $30 \mathrm{~mm}$, ferdén lehajló szélein $48 \mathrm{~mm}$ volt. A páncélzat tömege, a lövegtornyok forgó részének páncélzata nélkül, meghaladta az 5000 tonnát. (A RADETZKY-osztálynál ez

4. ábra. Színes grafika egy képeslapról, amely az 1916-os állapotot mutatja

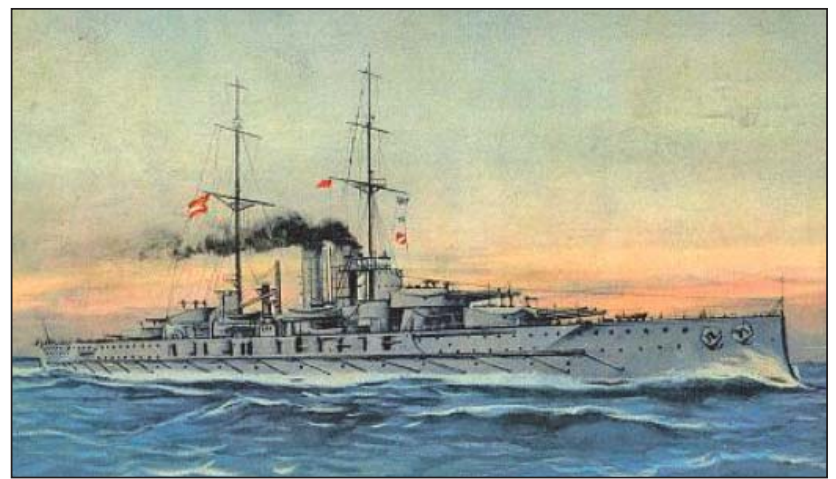


2. táblázat. A hajógőzgépek és -gőzturbinák múszaki mutatói ${ }^{8}$

\begin{tabular}{|c|c|c|c|c|c|}
\hline Év & 1798 & 1860 & 1870 & 1884 & 1910 \\
\hline Gőzgép/gőzturbina 1 LE-re eső tömege & 800 kg & $250 \mathrm{~kg}$ & $150 \mathrm{~kg}$ & $100 \mathrm{~kg}$ & $50 \mathrm{~kg}$ \\
\hline 1 LE-re eső szénfogyasztás óránként & $6 \mathrm{~kg}$ & $1,7 \mathrm{~kg}$ & $1 \mathrm{~kg}$ & $0,9 \mathrm{~kg}$ & $0,7 \mathrm{~kg}$ \\
\hline Gőznyomás & 2-3 bar & 5 bar & 6 bar & 7-12 bar & 15-16 bar \\
\hline Hatásfok & $5 \%$ & $10 \%$ & $13 \%$ & $14 \%$ & $15 \%$ \\
\hline
\end{tabular}

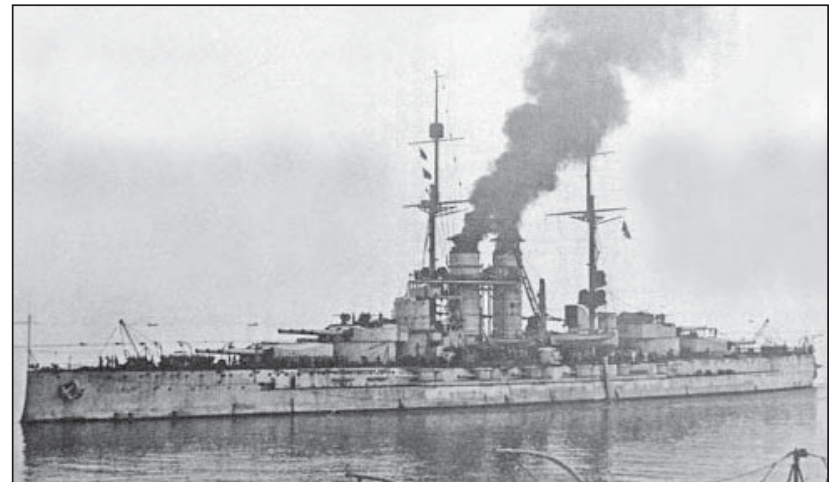

5. ábra. A hajó lőgyakorlatra készül, ezért fútik a kazánokat

az érték 3700 tonna volt.) A páncélzat anyaga $100 \mathrm{~mm}$ vastagság felett Krupp cementált acél $(K C)$, ennél vékonyabb lemezek esetén Krupp acél (K), illetve a páncélfedélzetek esetében Siemens-Martin acél (SM) volt.

A 19. század első felében a hajógőzgépek fajlagos teljesítmény-tömeg aránya, illetve fajlagos szénfogyasztása még meglehetősen kedvezőtlen volt (lásd: 2. táblázat). Csak többszörös expanziójú, kompaund (összetett) gőzgépek létrehozása, majd a gőz túlhevítése, a vízcsöves kazánok bevezetése és a füstgázos tápvíz-előmelegítés, illetve a kondenzátor bevezetése, a síktolattyús vezérlőszerkezetek, a gőzturbina megvalósítása (Parsons, 1884), továbbá a 15 bar feletti gőznyomás és az olajtüzelés bevezetése tette lehetővé a 15\% feletti hatásfok megvalósítását a 19. század végére. ${ }^{7}$

A fent felsorolt hatásfokjavító megoldások közül a SZENT ISTVÁN dreadnought meghajtási rendszerében a kiegészítő olajtüzelést, a gőz túlhevítését és a kondenzátort is alkalmazták, emellett - a VIRIBUS UNITIS dreadnoughtosztály többi hajóegységéhez képest - elméletileg nem 2, hanem 8 órán keresztül volt képes maximális, 21 csomós sebességgel haladni. ${ }^{9}$ (Ez a próbautak szerint a gyakorlatban csak 20,3 csomó volt. - Szerk.)

A Ganz és Tsa. Rt.-nek, amelynek a hajógépet is meg kellett építenie, az Angol-Osztrák Bankon keresztül olyan üzleti és technológiai kapcsolatai voltak, amelyek alapján a SZENT ISTVÁN-ba Babcock \& Wilcox típusú kazánokat építettek be. A Danubiusnak már nagy tapasztalata volt a Babcock \& Wilcox rendszerű kazánok gyártása terén. ${ }^{10}$ Előnyei miatt több élenjáró hajóépítő alkalmazott ilyen típusú kazánokat. Először az amerikai haditengerészet fedezte fel e kazántípus előnyeit. Anglia 1905-ben az addigi Belleville és Niclausse kazán helyett a dreadnoughtokba szintén Babcock \& Wilcox kazánt épített be, mert szénfogyasztásuk kisebb volt, mint a többi típusé. ${ }^{11}$ Előnyös volt tehát a SZENT ISTVÁN dreadnought kazántípus választása. Emellett „a Danubius gyártású Babcock-Wilcox kazán túlhevítővel készült, ezért teljesítménye $6 \%$-kal volt több a szerződésben előírtnál: 26550 LE (19 600 kW) lett, sebessége ezzel 21 csomóra emelkedett."12
1912. január 29-én lefektették a hadihajó gerincét, két héttel a VI. tervszámú (PRINZ EUGEN) hajó után, amely Triesztben épült. A névadás Ferenc József császári és királyi beavatkozása és döntése után zajlott le, így a IV. tervszámú lett a VIRIBUS UNITIS, az V. a TEGETTHOFF, a VI. a PRINZ EUGEN, a VII. a SZENT ISTVÁN.

A tervek átalakítását már említettük, a gépészet miatt lett a hajó egyedi, két hajócsavaros.

A SZENT ISTVÁN fő tüzérségének Škoda gyártmányú, béléscsöves rendszerű lövegei $305 \mathrm{~mm}$ űrméretűek voltak. A 305 mm-es ágyúk hármasával voltak elhelyezve a lövegtoronyban. A VIRIBUS UNITIS-t, majd a SZENT ISTVÁN-t konstruáló mérnök „gárda tervezte meg elsőként a világon a hajó-nehéztüzérség elhelyezését háromlöveges forgótoronyban."13 Azonban 1909 januárjában nyilvánossá vált a hír, amely szerint az új olasz „Dreadnought”-ot - a későbbi DANTE ALIGHIERI-t is - hármas lövegtoronnyal szerelik fel. A SZENT ISTVÁN-nál alkalmazott, eltolt magasságú toronyelrendezés helyett azonban kedvezőtlenebb módon, az egy síkba épített toronyelrendezést alkalmazták, ami csökkentette a tűzerőt. Később az amerikai dreadnoughtépítés is a VIRIBUS UNITIS osztálynál alkalmazott megoldást alkalmazta, igazolva a lövegtorony-elrendezés helyes megválasztását.

A torony tömege kompletten a lövegekkel, lövegtalpakkal és a páncélzattal 652,9 tonna volt. A cső űrmérethoszsza L/45 értékű volt. A cső tömege a zárral együtt 54300 kg. Tűzgyorsasága 2-3 lövés/min. Egy oldal-össztűz során 5400 kg gránátot lőtt ki a hajó, 800 m/s lövedék-kezdősebességgel, $18 \mathrm{~km}$ maximális lőtávolságra. ${ }^{14}$

6. ábra. A 4 darab hármas toronyban elhelyezett 12 darab $305 \mathrm{~mm}$-es löveg jelentős tűzerőt képviselt (Fotó: dr. Hüvös Ferenc modellje)

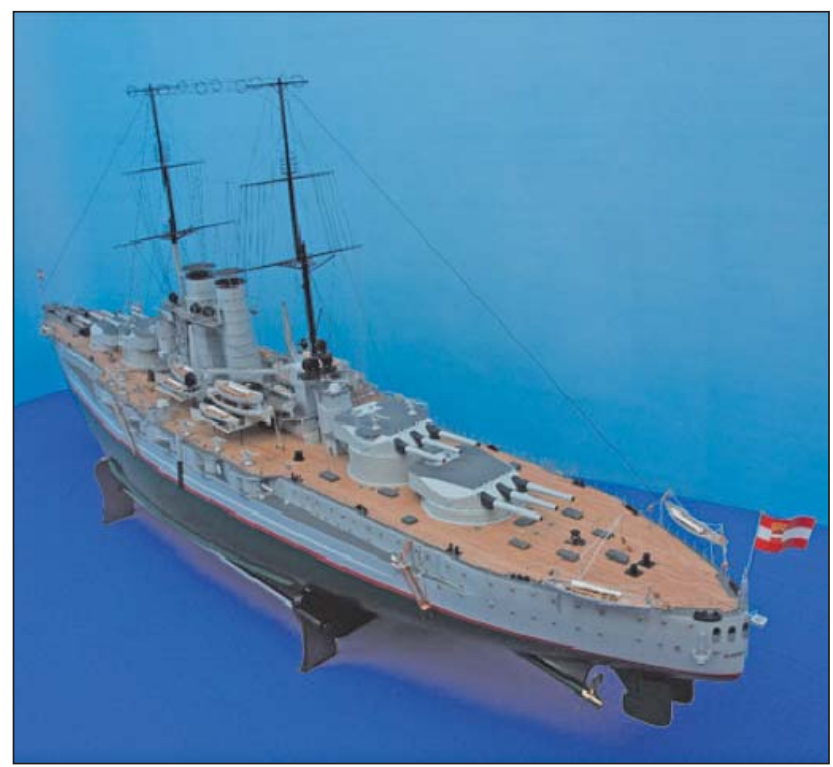


3. táblázat. A SZENT ISTVÁN dreadnought müszaki-harcászati adatai

\begin{tabular}{|c|c|c|}
\hline \multicolumn{2}{|c|}{ Gerincfektetés } & 1912. január 29. \\
\hline \multicolumn{2}{|c|}{ Vízre bocsátás } & 1914. január 17. \\
\hline \multicolumn{2}{|c|}{ Átadás } & 1915. december 13. (bizottságnak: november 17.) \\
\hline Vízkiszorítás & $\begin{array}{l}\text { - névleges } \\
\text { - tényleges } \\
\text { - felszerelve }\end{array}$ & $\begin{array}{c}20014 \mathrm{t} \\
20008,3 \mathrm{t} \\
21689 \mathrm{t}\end{array}$ \\
\hline Hosszúság & $\begin{array}{l}\text { - teljes } \\
\text { - vízvonalon } \\
\text { - függélyek nélkül }\end{array}$ & $\begin{array}{l}152,18 \mathrm{~m} \\
151,4 \mathrm{~m} \\
143,0 \mathrm{~m}\end{array}$ \\
\hline \multicolumn{2}{|c|}{ Max. szélesség } & $27,998 \mathrm{~m}$ \\
\hline Merülés & $\begin{array}{l}\text { - elöl } \\
\text { - hátul }\end{array}$ & $\begin{array}{l}8,58 \mathrm{~m} \\
8,37 \mathrm{~m}\end{array}$ \\
\hline \multirow{2}{*}{\multicolumn{2}{|c|}{$\begin{array}{l}\text { Babcock-Wilcox kazán } \\
\text { AEG-Curtiss turbina } \\
\text { Hajócsavar }\end{array}$}} & $\begin{array}{c}12 \mathrm{db} \text { (18 atü) } \\
2 \mathrm{db} 25000 \text { LE (névleges), } 26400 \text { LE (próbaúton) } \\
2 \mathrm{db} \text {, átmérő } 4,0 \mathrm{~m}\end{array}$ \\
\hline & & 20 csomó \\
\hline \multicolumn{2}{|c|}{ Hatótávolság } & 4200 tengeri mérföld/10 csomóval \\
\hline Páncélzat & $\begin{array}{l}\text { - alapozás } \\
\text { - oldalán } \\
\text { - fedélzet } \\
\text { - pc. tornyokon } \\
\text { - parancsnoki torony } \\
\text { - ütegfedélzet }\end{array}$ & $\begin{array}{c}80 \mathrm{~mm} \text { teakfa, ezen } 18 \mathrm{~mm} \text { vaslemez } \\
280 \mathrm{~mm} \\
48 \mathrm{~mm} \\
280 \mathrm{~mm} \\
280 \mathrm{~mm} \\
180 \mathrm{~mm}\end{array}$ \\
\hline \multicolumn{2}{|c|}{ Fegyverzet: fötüzérség } & $\begin{array}{c}12 \mathrm{db} 305 \mathrm{~mm} \text { L/45 Škoda löveg } \\
12 \mathrm{db} 150 \mathrm{~mm} \text { L/50 löveg } \\
18 \mathrm{db} 66 \mathrm{~mm} \text { L/45 (légvédelmi) löveg } \\
4 \mathrm{db} \text { TT 53,3 cm torpedóindító } \\
\text { plusz } 6 \mathrm{db} 66 \mathrm{~mm} \text { L/48 légvédelmi löveg a B és Y tornyok tetején } \\
2 \mathrm{db} 66 \mathrm{~mm} \text { L/48 légvédelmi löveg cserélve } \\
4 \mathrm{db} \text { új } 66 \mathrm{~mm} \text { L/50 légvédelemre }\end{array}$ \\
\hline \multicolumn{2}{|c|}{$\begin{array}{l}\text { Legénység } \\
\text { - 1918-ban: }\end{array}$} & $\begin{array}{c}\text { normál } 1046 \text { fő } \\
1094 \text { fő }\end{array}$ \\
\hline
\end{tabular}

Az ágyú gyorstüzelő ékzáras rendszerű volt, fémhüvelyes lőszerrel tüzelt. A Monarchia ipara ugyanis a legnagyobb ürméretig is képes volt lőszerhüvelyeket gyártani. ${ }^{15}$ 1897-től a magyar hadiipar is bekapcsolódott a haditengerészeti lőszergyártásba, amelynek beszállítói részarányát fokozatosan $50 \%$-ra növelték. ${ }^{16}$

A négy darab hármas toronyban elhelyezett 12 löveg tűzvezetését eredetileg két 3658 mm-es és négy, a lövegtornyokban felszerelt $2743 \mathrm{~mm}$-es angol Barr\&Stroud távmérő biztosította. Később, a találati pontosság növelése érdekében bevezettek egy olyan rendszert, amely tengelykapcsolók segítségével egymáshoz rögzítette egy-egy torony lövegcsöveit. Az együtt mozgó, összekapcsolt csövekkel a lőtávolság ugyan 20 km-röl 18,5 km-re csökkent a kisebb csőemelkedési szög miatt, viszont megnövekedett a találati valószínüség. Az 1914 tavaszán kipróbált rendszert az osztály első két hajójába utólag építették be. ${ }^{17}$

Összegezve a hajó műszaki jellemzőit, illetve összevetve a korszak más - potenciális ellenfélként felmerülő dreadnoughtjaival (4. táblázat), elmondható, hogy a SZENT ISTVÁN a korszak hasonló kategóriájú hajóinál valamivel szerényebb harcászati értékeket mutatott. (Kivételt képez ez alól a DANTON dreadnought.) Ugyanakkor a Kesselring módszerrel végzett összehasonlítás nem érzékeltet olyan műszaki előnyöket, mint a SZENT ISTVÁN-on a szintben eltolt ágyútornyokból adódó nagy szabadságfokú kilövési lehetőség, ami az adott rendelkezésre álló tűzerő hatékony kihasználását jelentette a harcban - viszont a hajó stabilitásának csökkenését is eredményezte a magasabb súlypont miatt. Nem érzékeltet a táblázat olyan adatokat sem, mint a SZENT ISTVÁN képessége a 8 órás maximális sebesség tartásra - ami a kazánok konstrukciójából fakadt (viszont jelentősen növelte a hajó szerkezeti tömegét).

A legfontosabb összevetési felület a SZENT ISTVÁN és a DANTE ALIGHIERI között az erőegyensúly felvázolása lenne. A fent leírtak tükrében azonban ez - a táblázat adatainak figyelembevétele mellett - komplexebb elemzést igényelne, még akkor is, ha a Kesselring módszer az olasz dreadnought előnyét mutatja ki.

A SZENT ISTVÁN dreadnoughtot nagy ünnepség keretében, 1914. január 17-én bocsátották vízre.

1914. július 28-án a Monarchia hadat üzent Szerbiának, megkezdődött az I. világháború. A hajó befejezése sürgőssé vált, de nem volt hozzá elegendő anyag és a fiumei építők tapasztalatlanok voltak. Ezért a SZENT ISTVÁN-t 1914 augusztusában átvitték Pólába, az ottani Tengerészeti Arzenál fejezte be a felszerelését. 1915. december 13-án vette át a haditengerészet és december 23-án állt 


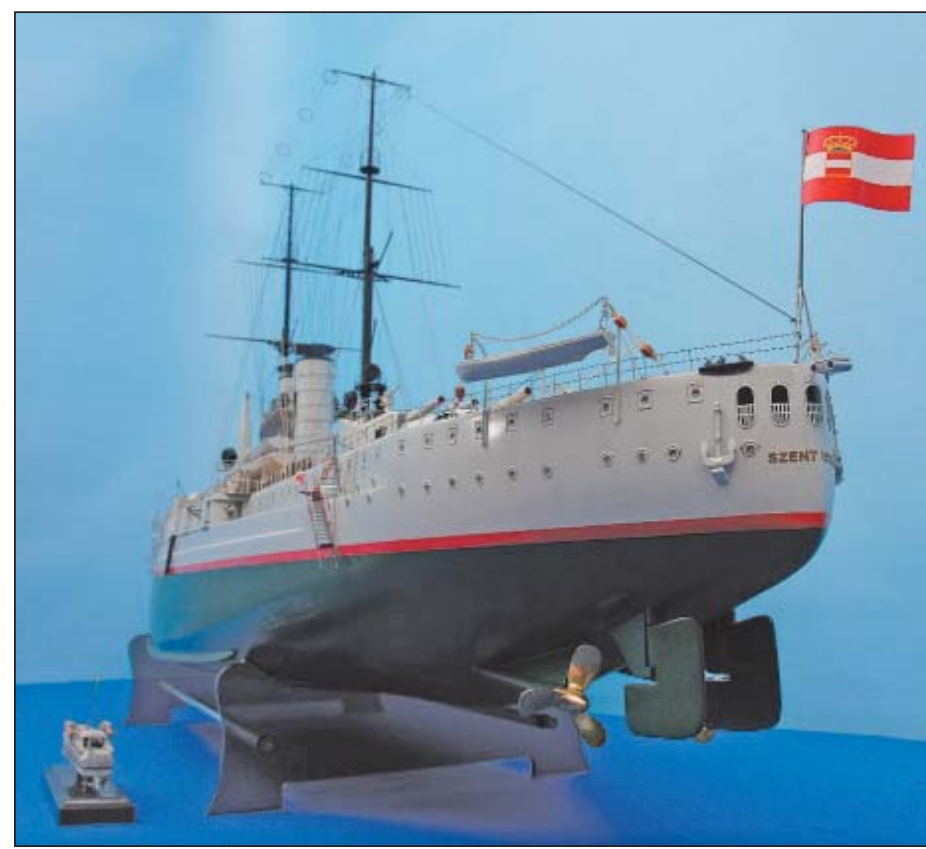

7. ábra. A 2 db AEG gőzturbina beépítése következtében a hajót át kellett tervezni két hajócsavaros kialakításúra (Fotó: dr. Hüvös Ferenc modellje) szolgálatba. A hajó műszaki adatait a 3. táblázat tartalmazza.

Két nevezetes látogatás történt a fedélzetén. A dreadnoughtot 1916. december 15-én az új uralkodó IV. Károly, majd 1917. december 12-én II. Vilmos német császár látogatta meg.

Egy fontosabb átépítés zajlott le rajta. 1917-ben a $B$ és C lövegtorony tetején még 2-2 db 7,5 cm-es légvédelmi ágyút szereltek fel, amelyek új típusok voltak. Ezzel egy időben az A és $D$ lövegtorony tetejére szerelt régi lövegeket leszerelték.

A VIRIBUS UNITIS és a SZENT ISTVÁN a kémények tetején, a felső sík felett 1,5 m-rel felszerelt kb. 1,0 méter magas kúpos védőtetőt kapott, repülőbombák elleni védelemül.

1917-18-ban az olasz légitámadások egyre fokozódtak Póla ellen, a véletlen bombatalálat ellen építettek ki védelmet. A hátsó kémény mögötti 2 darab szellőztető kürtőt és a parancsnoki torony tetejéről a két kéményre támaszkodó jobb és bal oldali fényszóró hidat csak ezen a hajón építették be. Ezekre 3-3 darab, síneken mozgó fényszóró volt felszerelve, amelyek emelték a hajó súlypontját, így rontva annak stabilitását. (Soha nem használták őket; amikor kellett volna, nem voltak bekapcsolva.)

A hajó kifutásai a Fasana-csatornába vezettek a lőgyakorlatokra. Ettől eltekintve csak 1916. március

4. táblázat. Összehasonlító adatok a SZENT ISTVÁN számításba jöhető ellenfeleiről (D.Sz.P.)

\begin{tabular}{|c|c|c|c|c|c|c|c|}
\hline & & $\begin{array}{l}\text { SZENT } \\
\text { ISTVÁN }\end{array}$ & DANTON & $\begin{array}{l}\text { JEAN } \\
\text { BART }\end{array}$ & $\begin{array}{c}\text { DANTE } \\
\text { ALIGHIERI }\end{array}$ & $\begin{array}{l}\text { CONTE DI } \\
\text { CAVOUR }\end{array}$ & Ideál \\
\hline \multirow{4}{*}{$\begin{array}{l}\text { Vízkiszorítás } \\
\text { (t) }\end{array}$} & \multirow{2}{*}{ névleges } & 20008 & 18400 & 25000 & 19500 & 23088 & 25000 \\
\hline & & 8,00 & 7,36 & 10,00 & 7,80 & 9,24 & 10 \\
\hline & \multirow{2}{*}{$\max }$. & 21689 & 19950 & 26000 & 21800 & 25086 & 26000 \\
\hline & & 8,34 & 7,67 & 10,00 & 8,38 & 9,65 & 10 \\
\hline \multirow{2}{*}{\multicolumn{2}{|c|}{ Hosszúság (m) }} & 152,18 & 116,6 & 168,0 & 168,1 & 176,1 & 176,1 \\
\hline & & 8,64 & 6,62 & 9,54 & 9,55 & 10,00 & 10 \\
\hline \multirow{2}{*}{\multicolumn{2}{|c|}{$\begin{array}{l}\text { Gépteljesítmény } \\
\text { (LE max.) }\end{array}$}} & 26400 & 22500 & 28000 & 32200 & 31278 & 32200 \\
\hline & & 8,20 & 6,99 & 8,70 & 10,00 & 9,71 & 10 \\
\hline \multirow{2}{*}{\multicolumn{2}{|c|}{ Max. sebesség (csomó) }} & 20,4 & 19,25 & 22,6 & 24,2 & 22,2 & 24,2 \\
\hline & & 8,43 & 7,95 & 9,34 & 10,00 & 9,17 & 10 \\
\hline \multirow{3}{*}{ Fegyverzet } & $(\mathrm{mm})$ & 305 & 305 & 305 & 305 & 305 & - \\
\hline & (db) & 12 & 4 & 12 & 12 & 13 & 13 \\
\hline & & 9,23 & 3,08 & 9,23 & 9,23 & 10,00 & 10 \\
\hline \multirow{6}{*}{$\begin{array}{l}\text { Páncélzat } \\
(\mathrm{mm})\end{array}$} & \multirow{2}{*}{ felül } & 100 & 150 & 180 & 100 & 130 & 180 \\
\hline & & 5,56 & 8,33 & 10,00 & 5,56 & 7,22 & 10 \\
\hline & \multirow{2}{*}{ oldalt } & 280 & 270 & 270 & 250 & 250 & 280 \\
\hline & & 10,00 & 9,64 & 9,64 & 8,93 & 8,93 & 10 \\
\hline & \multirow{2}{*}{ alul } & 100 & 150 & 180 & 150 & 130 & 180 \\
\hline & & 5,56 & 8,33 & 10,00 & 8,33 & 7,22 & 10 \\
\hline \multicolumn{2}{|c|}{ Pontszám } & 71,96 & 65,98 & 86,45 & 77,78 & 81,14 & 90 \\
\hline \multicolumn{2}{|c|}{$\begin{array}{l}\text { Pontszám aránya az } \\
\text { ideálishoz képest }\end{array}$} & 0,80 & 0,73 & 0,96 & 0,86 & 0,90 & \\
\hline
\end{tabular}

(Félkövér betűvel a hajók műszaki adatai, normál betütípussal a Kesselring összehasonlító módszer számítási értékei kerültek feltüntetésre.) 


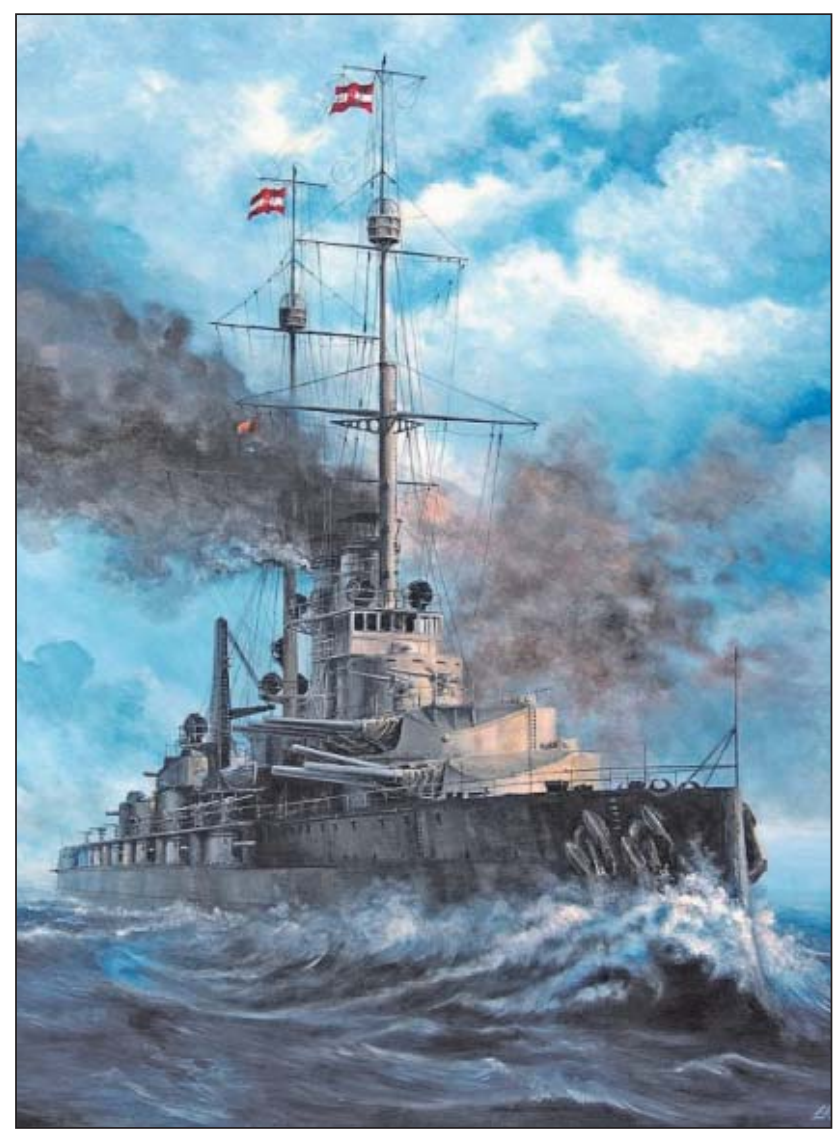

8. ábra. Színes festmény a hajóról (amely idealizált ábrázolás, hiszen az árbócok csúcsán soha nem volt hadilobogó, illetve egyszerre két lobogót sem alkalmaztak)

15-16-án volt egy útja Pago szigetéhez, és vissza. Összesen 937 napon át állt szolgálatban és ebből 54 napon át volt távol Pólától.

Egyetlen bevetésére 1918. június 9-10-én került sor, amely egyben az utolsó volt.

\section{A SZENT ISTVÁN ELSÜLLYEDÉSE}

Az 1918. február 27-én a hajóhad parancsnokának kinevezett nagybányai Horthy Miklós ellentengernagy nyáron nagy bevetést tervezett az újra kiépített otrantói tengerzár szétzúzására. Az antant erők újra létrehozták az 1917 nyarán megsemmisített hálózárat, amelyet nehezebb hadihajókkal is védtek.

A tengeralattjárók szabad útjának megteremtésére a záró hajók többségét el kellett süllyeszteni. Ezt a feladatot a SAIDA osztály négy gyorscirkálójának (SAIDA, ADMIRAL SPAUN, HELGOLAND, NOVARA) és a TÁTRA osztály négy tagjának (TÁTRA, CSEPEL, LIKA II, TRIGLAV II) kellett elvégezni, ezzel együtt 4 torpedónaszád Otrantó előtt volt várakozó állásban.

A támadás hírére az antant erők nyilván kifutnak Valónából és Brindisiből, ezekkel az öt csoportban felálló osztrák-magyar erők felvették volna a harcot.

A felvonulási tervet itt nem tárgyaljuk, ennek lényege, hogy $41^{\circ}$ É szélesség, $17^{\circ} \mathrm{K}$ hosszúság pozíciójában állt a TEGETTHOFF a VELEBIT romboló és a négy torpedónaszád fedezetében, a $41^{\circ}$ É szélesség, $18^{\circ} \mathrm{K}$ hosszúság pozíciójában a közelben állt volna a SZENT ISTVÁN 5 torpedónaszád fedezetében.

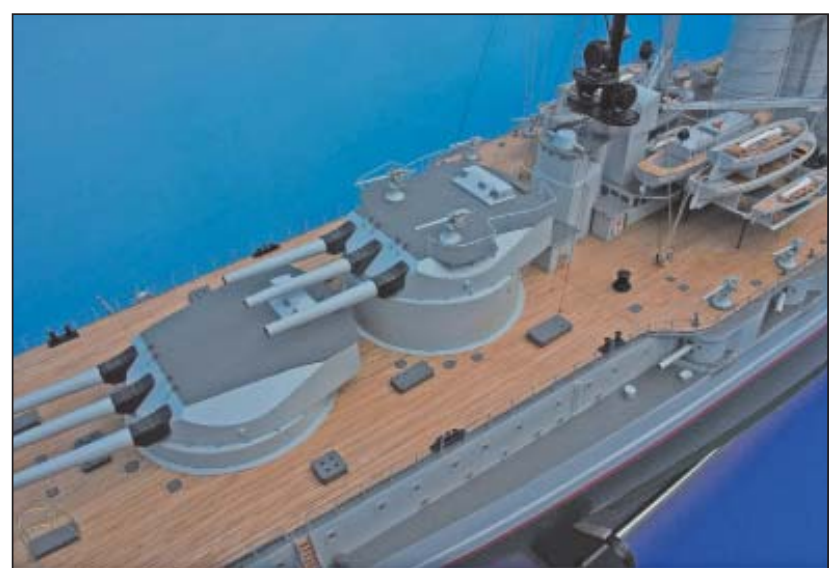

9. ábra. A lövegtornyok eltolt szintű elrendezése nagy szögtartományú lövés-kiváltási lehetőséget biztosított (Fotó: Dr. Hüvös Ferenc modellje)

A flottaegységek első részének felvonulása tervszerűen lezajlott, 1918. június 9-én 22:15-kor Pólából kifutott a SZENT ISTVÁN csoport.

Eleve késéssel indultak el, mert 45 perc kiesést okozott a védelmi zár kapujának kinyitása. Müszaki hiba is bekövetkezett, a SZENT ISTVÁN jobb oldali turbinája túlmelegedett, ezért csak 12 csomós sebességgel mehettek az előirt 16 helyett. Ez június 10-én hajnalban, 03:30-kor már 1,5 óra késedelmet jelentett.

A kötelékben elöl a VELEBIT romboló haladt, mögötte 1000 méterrel a SZENT ISTVÁN, majd 800 méterrel hátrább a TEGETTHOFF. Jobbra és balra 800-800 méter távolságban haladt a kíséret. Balra a $79 \mathrm{~T}$, a $78 \mathrm{~T}$ és a $87 \mathrm{~F}$, jobbra a 77T, 76T és a 81T torpedónaszádok.

Ezzel egyidőben Anconából két olasz torpedónaszád kivontatta a MAS 15-ös és 21-es számú siklónaszádot.

Ezek a feladat szerint a Premuda-sziget fölötti Gruiza és Selve-sziget között vadásztak hajókra és aknákat kerestek. Éjféltől 02:30-ig várakoztak, ekkor elindultak visszafelé, hogy 04:45-kor találkozzanak a vontató torpedónaszádjaikkal. A MAS 15-ös parancsnoka Luigi Rizzo korvettkapitány volt, aki korábban - 1917. december 10-én - a trieszti-öbölben horgonyzó WIEN partvédő páncélost elsüllyesztette.

Támadásra indult a hajnali szürkületben. Úgy haladt át a 77T és 76T torpedónaszádok között, hogy nem vették észre. Mit ért a figyelőszolgálat és az őrség, amikor a két hajó között alig 500 méter volt a távolság?!

Rizzo 500 méterről lőtte ki mindkét torpedóját a SZENT ISTVÁN-ra és 03:30-kor két robbanás rázta meg a dreadnoughtot. Ekkor vette észre a 76T torpedónaszád a

10. ábra. Színes festmény a SZENT ISTVÁN dreadnoughtról. A hajó csak gyakorlatok során tüzelt lövegeiből, csatában soha sem vett részt

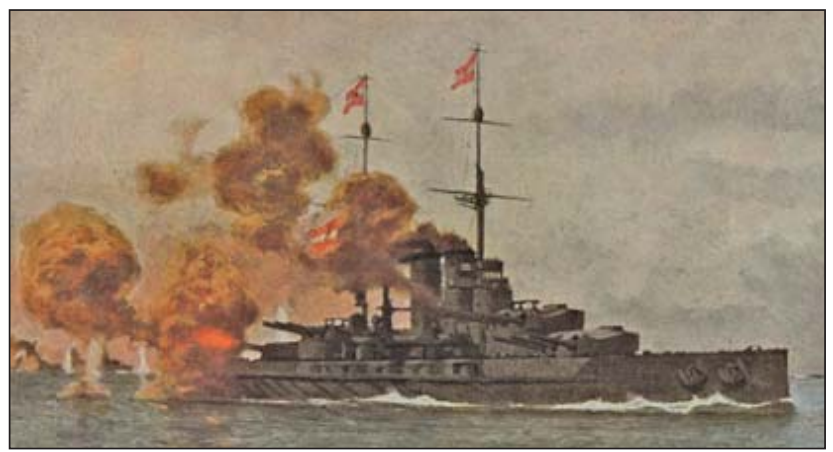




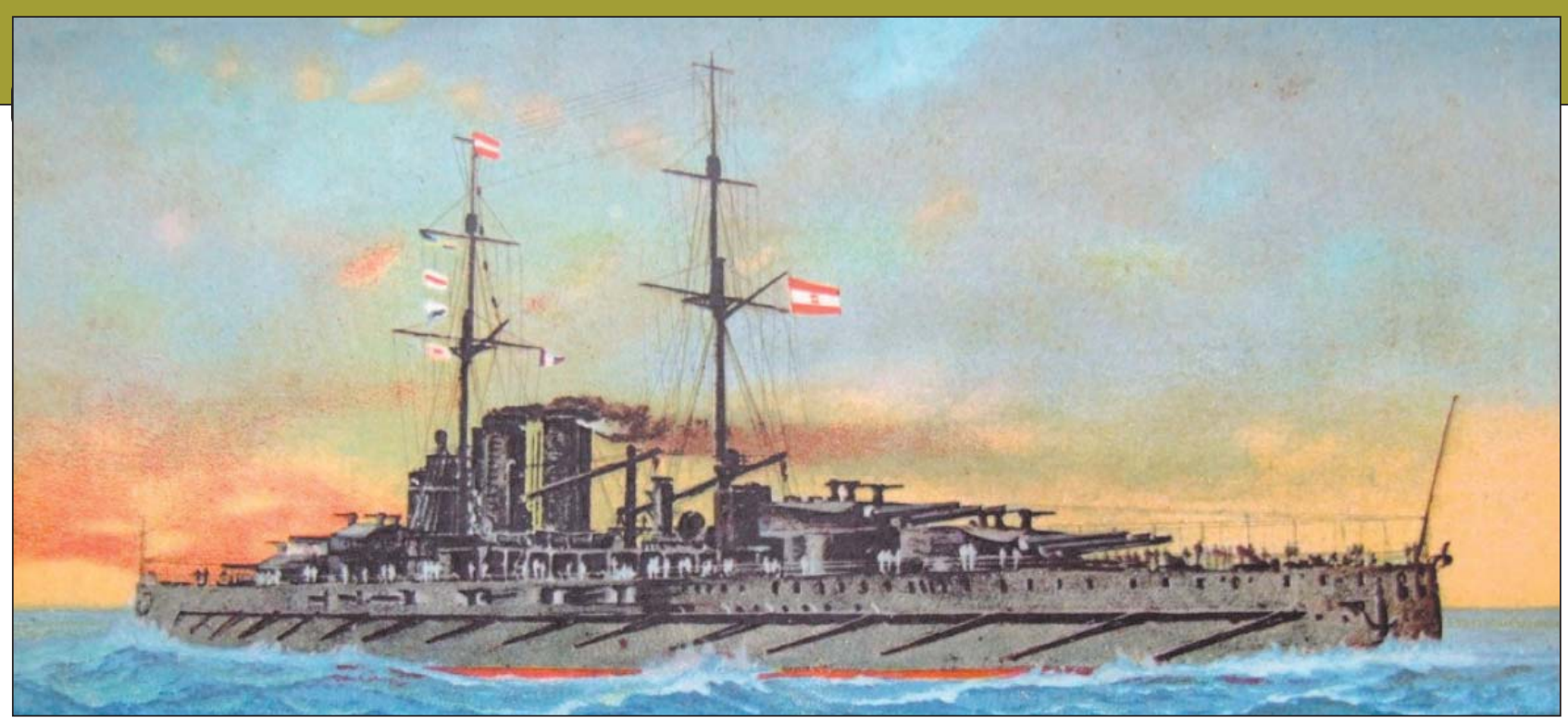

11. ábra. A SZENT ISTVÁN egy színes képeslapon, háború alatti kiadás

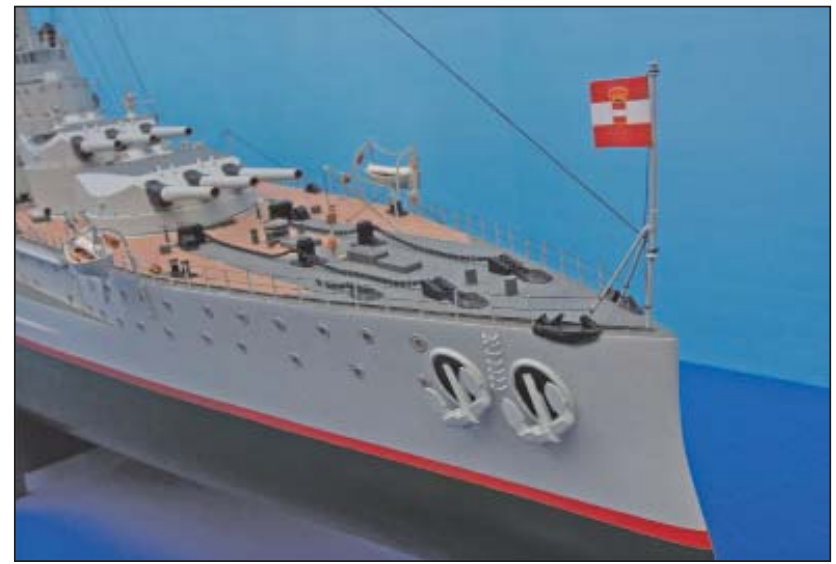

12. ábra. A horgonyokat német cég gyártotta (Fotó: Dr. Hüvös Ferenc modellje)

forduló MAS 15-öst, tüzet nyitott és üldözni kezdte, de az elmenekült.

A MAS 21-es a TEGETTHOFF-ra lőtte ki két torpedóját, ezek nem találtak, a naszád elmenekült. A magyar hajót Premuda szigettől 9 mérföldre, DK-i irányban találták el, le is állt.

A két torpedó robbanása átütötte a jobb oldali első és második kazánház falát, és átszakította a kettő közti válaszfalat is. A vízoszlop több száz méterre csapott fel, a hajó $10^{\circ}$-kal jobbra dőlt a vízbetörés miatt, a lékek 5-6 méterrel a vízszint alatt voltak. A pozíció $44^{\circ} 16^{\prime}$ északi szélesség, és $14^{\circ} 23^{\prime}$ keleti hosszúság volt, a parancsnok Heinrich Seitz von Treffen sorhajókapitány azonnal elrendelte a mentést és

\section{3. ábra. A VIRIBUS UNITIS dreadnought-osztály három} hajóegysége

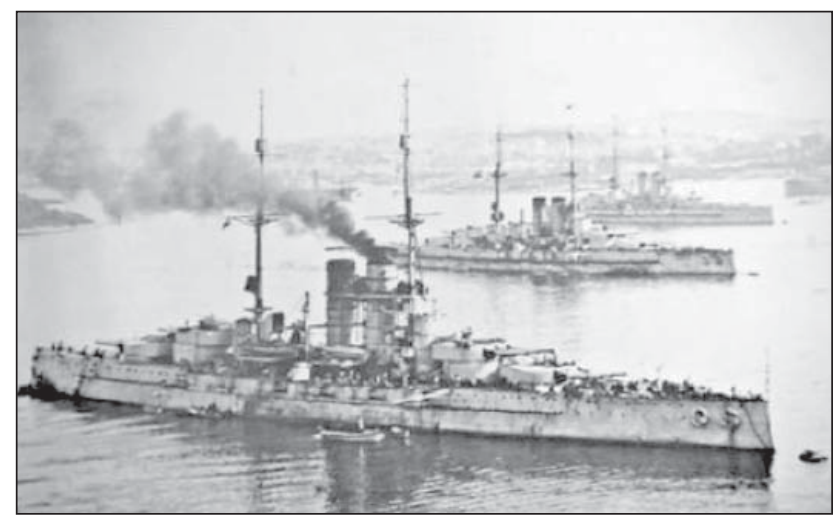

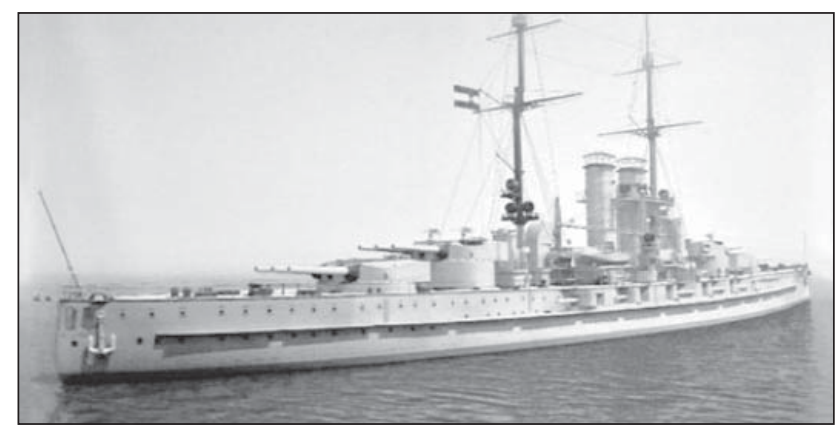

14. ábra. A SZENT ISTVÁN dreadnought Pólában horgonyoz az 1917-es átépítés utáni állapotában

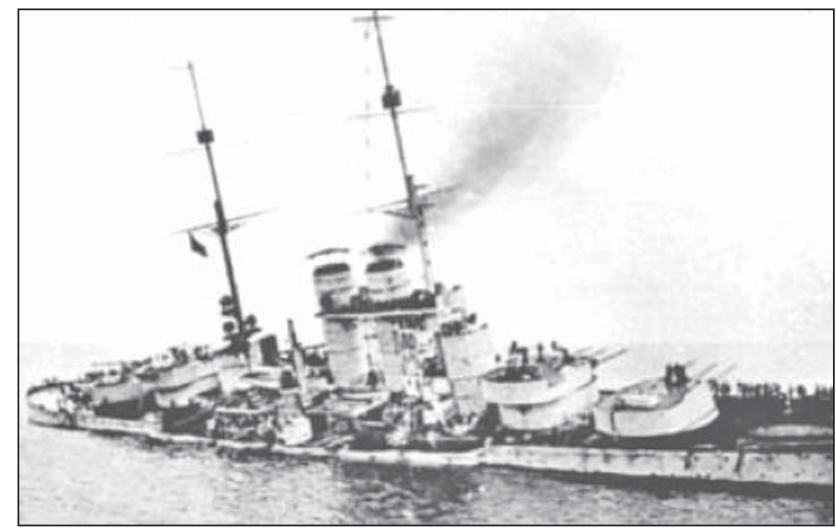

15. ábra. A hajó megtorpedózása után mintegy két órával, már erösen jobbra dőlve

a kárelhárítást. A vontatási kísérlet sem sikerült, 04:45-kor a kábelek elszakadtak. A léket betömni sem sikerült, a dőlést $7^{\circ}$-ra tudták mérsékelni, a négy lövegtornyot balra fordították és a készenléti lőszert a vízbe dobták.

Ez sem volt elég, a réseken ömlött be a víz. Seitz kiadta a parancsot a hajó elhagyására. A legénység 38 tiszt és 1056 fő legénység volt, azaz 1094 fő, ebből a torpedónaszádok kimentettek 1005 főt, 89 fő hősi halált halt.

A hajó 06:05-kor jobbra dőlve felborult, és 06:12-kor víz alá merült. A veszteség a kárelhárító osztag és a géptermek embereiből került ki, akik már nem tudták elhagyni a dőlő hajót. A 89 főből 42 magyar volt, névsoruk dr. Csonkaréti Károly forrásként jelölt könyvének 216-217. oldalán található.

A hajó részletes történetét Ervin Sieche írta meg. Monográfiája - Benczúr László rajzaival - a Haditechnika 2001. évfolyam 2., 3., 4. számában jelent meg. 
FELHASZNÁLT IRODALOM

Horváth János: Az első magyar építésű csatahajó, a SZENT ISTVÁN Haditechnika, 1988/3. 30-34.;

Balogh Tamás - Csepregi Oszkár: A Szent István csatahajó és a csatahajók rövid története. General Press Kiadó, 2002.;

Krámli Mihály: Az S. M. S. SZENT ISTVÁN Hadtörténelmi Közlemények 2005/1-2.;

Siegfried Breyer: Schlachtschiffe und Schlachtkreuzer 1905-1970. I.F. Lehmanns Verl. München, 1970.;
Dr. Csonkaréti Károly: Császári és királyi hadihajók. Hajja és Fiai Könyvkiadó, Debrecen, 2002.;

Erwin F. Sieche: Őfelsége SZENT ISTVÁN nevű hadihajója. Magyarország egyetlen szerencsétlen sorsú dreadnoughtja. Haditechnika: 2001/2. sz. pp. 15-20. I. rész, 2001/3. sz. pp. 18-22. II. rész, 2001/4. sz. pp. 5-9. III. rész;

Csák Ervin: Hajók és hajózási módszerek. Műszaki Könyvkiadó, Budapest, 1969.

Komondy Zoltán: Gőzgépek, gőz- és gázturbinák II. k. Tankönyvkiadó, Budapest, 1954.

\footnotetext{
JeGYZETEK

1 A „dreadnought” csatahajó-típus az angol Dreadnought nevű, 1905-ben épült hadihajóról kapta a nevét, amely az első modern „,csupa nagyágyús” („all big gun battleship”) csatahajó volt, forgó tornyokkal. A csatahajó elnevezést hivatalosan csak 1922-ben vezették be, de a későbbi munkák önkényesen már az I. világháborúban harcolt egységekre is alkalmazták.

2 Balogh Tamás - Csepregi Oszkár: A Szent István csatahajó és a csatahajók rövid története. General Press Kiadó, 2002. 43. o.

3 Uo. 52. o.

4 Uo. 46. o.

5 Erwin F. Sieche: Őfelsége Szent István nevű hadihajója Magyarország egyetlen, szerencsétlen sorsú dreadnoughtja I-III. rész. Haditechnika, 2001/2. sz.

6 Balogh Tamás - Csepregi Oszkár: A Szent István csatahajó és a csatahajók rövid története. General Press Kiadó, 2002. 62. o.

7 Csák Ervin: Hajók és hajózási módszerek. Műszaki Könyvkiadó, Budapest, 1969. 46-52. o. ill. Komondy Zoltán: Gőzgépek, gőz- és gázturbinák II. k. Tankönyvkiadó, Budapest, 1954. 10-13. o.

8 Csák Ervin: Hajók és hajózási módszerek. Műszaki Könyvkiadó, Budapest, 1969. 46-52. o. ill. Komondy Zoltán: Gőzgépek, gőz- és gázturbinák II. k. Tankönyvkiadó, Budapest, 1954. 10-13. o.
}

9 Balogh Tamás - Csepregi Oszkár: A Szent István csatahajó és a csatahajók rövid története. General Press Kiadó, 2002. 52. o.

10 A budapesti Parlament, a Vízművek, az Elektromos Művek és a Fővárosi Villamos-Vasút - mind Danubius gyártmányú BabcockWilcox rendszerű kazánokkal üzemeltek.

11 A Belleville típusú kazán 0,86kg/LE/h; a Niclausse típusú kazán 0,76 $\mathrm{kg} / \mathrm{LE} / \mathrm{h}$; a Babcock-Wilcox típusú kazán 0,69 kg/LE/h szénfogyasztás értéket adott.

12 Horváth János: Az első magyar építésű csatahajó, a SZENT ISTVÁN. Haditechnika, 1988/3. 30-34.

13 Uo. 30-34

14 Balogh Tamás - Csepregi Oszkár: A Szent István csatahajó és a csatahajók rövid története. General Press Kiadó, 2002. 77-78. o.

$15 \mathrm{Az}$ antantállamok ipara csak $15 \mathrm{~cm}$ űrméretig alkalmazta ezt a módszert. Nehéztüzérségük általában az úgynevezett zsáktöltényt használta, amely nem volt olyan biztonságos, mint a hüvelytöltény.

16 Balogh Tamás - Csepregi Oszkár: A Szent István csatahajó és a csatahajók rövid története. General Press Kiadó, 2002. 41. o.

17 Krámli Mihály: Az S. M. S. SZENT ISTVÁN Hadtörténelmi Közlemények 2005/1-2.

\section{A somogyi rosseb hadosztály a Don-kanyarban}

A Zrínyi Kiadó 2015-ben jelentette meg Lukács Bence Ákos és Szabó Péter: A somogyi rosseb hadosztály a Don-kanyarban - Hadiokmányok, harctéri naplók, tábori levelezőlapok, visszaemlékezések és sajtóhíradások a magyar királyi 10. honvéd könnyü hadosztály történetéhez 1942-1943. című könyvét. Ez a kötet olyan értékes forráskiadvány, amely családi archívumokban őrzött korabeli hadiokmányok, harctéri naplók, feljegyzések, tábori levelezőlapok, illetve visszaemlékezések részletei alapján tárgyalja a hadtörténeti eseményeket kronologikus sorrendben. Somogy megye „rosseb bakái” a magyar 2. hadsereg 10. könnyű hadosztály kötelékében, közel 14000 fővel vonultak ki 1942. május végén a keleti frontra, a Don menti hadműveleti területre. A hadosztály nevében szereplő „rosseb" kifejezés Somogyban meglehetősen gyakori káromkodás volt, ezért eredetileg az első világháborúban harcoló somogyi 44. császári és királyi gyalogezredet hívták így. Ebből ered a második világháború alatt használt „rosseb hadosztály” kifejezés is. A kötetben tárgyalt kaposvári parancsnokságú magyar királyi 10. könnyű hadosztály leghosszabb és legsúlyosabb második világháborús harctéri tevékenysége az 1942-43. évi keleti hadszíntéri hadmúveletekhez kötődik. A kötet hat fejezete a fronteseményeket mutatja be 1942 májusától 1943 májusáig. Prof. Dr. Szabó Péter alezredes, hadtörténész - a HM Hadtörténeti Intézet és Múzeum Hadtörténeti kutató osztályának vezető főtisztje - a Don-kanyar történetének neves hazai kutatója, míg Lukács Bence Ákos történész a Pázmány Péter Katolikus Egyetem Történelemtudományi Doktori Iskolájának doktorandusz hallgatója, a II. világháború hadtörténetének szakavatott kutatója.

A második világháborúban harcolt magyar honvédek a Don-kanyarban katonai kötelességüket teljesítették, főhajtást és tiszteletet érdemelnek. A könyv a hősi halált halt, nyomtalanul eltűnt vagy hadifogságban elhunyt somogyi honvédek emléke előtt tiszteleg. A kötet mintegy 80 oldalnyi képmellékletben zömében fekete-fehér ábrákat és térképeket tartalmaz. A kötetben említett katonák 1942-1945 közötti harctéri szolgálatára koncentráló - a második világháborús kitüntetéseiket is tartalmazó - rövid életrajzai a kötet végén találhatók. A kiadvány mellékletében, egy CDlemezen az egykori katonák és munkaszolgálatosok adatait ismerheti meg az olvasó. A könyv érdekes olvasmány lehet a hadtörténelem iránt érdeklődőknek. (D.Sz.P.)

Az 552 oldalas, keménytáblás, B5-ös méretű, mintegy 200 db fekete-fehér fotóval illusztrált könyv 6400 Ft-os áron kapható a könyvesboltokban, illetve közvetlenül a Zrínyi Kiadótól is, $20 \%$-os helyszíni kedvezménnyel. (Cím: 1087 Budapest, Kerepesi út 29/b., Tel.: 061459 5373, e-mail: gyoredina@armedia.hu). 